\title{
AC 2011-1719: PREPARING ENGINEERING GRADUATES FOR THE REAL WORLD
}

Jessica R. McCormick, Indiana University Purdue University Indianapolis

Beverly Radloff, Indiana University Purdue University, Indianapolis

Nancy Lamm, Indiana University Purdue University, Indianapolis

Terri L. Talbert-Hatch, Indiana University Purdue University, Indianapolis

Terri Talbert-Hatch is the Assistant Dean for the Purdue School of Engineering and Technology, IUPUI. In this position she is responsible for recruitment of undergraduate students and all scholarships. She is responsible for all marketing for the school including program brochures and the school's website. She also oversees the School's Career Services office and is the advisor to the school's student council. She received her Bachelor's in General Studies and M.S. in Adult Education at IUPUI. She is currently working on her dissertation toward an Ed.D. in Higher Education Administration at Indiana University. 


\title{
Preparing Engineering Graduates for the Real-World: The Butler University and Indiana-University Purdue-University Indianapolis Joint Engineering Dual Degree Program
}

\begin{abstract}
$\underline{\text { Abstract }}$
Engineers of today must understand the social, political, cultural and environmental impacts of technology and innovation. Engineering graduates from traditional programs are lacking in skills required to be successful after graduation. The engineering dual degree program encompasses the liberal arts, experiential education, and cultural and international exposure producing engineers ready for the real-world work environment.

Some research attention has been focused on traditional three-two programs or Bachelors/Masters programs; however little has been focused on dual degree programs where engineering and non-technical fields are paired together. These dual degree programs produce engineering graduates who are well rounded and can function in the society of today and the future. Through the incorporation of traditional engineering coursework and a strong background in the liberal arts, students become attractive candidates to employers. In addition, these graduates have the social understanding, human interaction and communication skills that the traditional engineering student does not possess.
\end{abstract}

This research paper will address the benefits of the Engineering Dual Degree Program (EDDP) and show how its graduates are better prepared for work upon graduation. The EDDP is a unique partnership between Butler University and the Purdue School of Engineering and Technology at Indiana-University Purdue-University Indianapolis (IUPUI). The data will be gathered from graduates from the EDDP and undergraduate engineering at IUPUI as far back as 2004, which is the first year the dual degree program graduated students. The results will be analyzed in comparison between the two groups in order to determine whether a disparity exists between job placement and opportunities for graduates of both programs. The researchers believe data will show that the EDDP graduates are more successful in their job search than their peers at IUPUI. In addition, responses to the open ended questions will provide feedback on the benefits of the program from graduate perspectives.

\section{Introduction}

As the engineering profession continues to evolve, so should the engineering curriculum. It is the responsibility of the educational program to prepare graduates who are ready to work in the realworld. Engineering students have always been taught to be excellent problem-solvers. However, companies are looking to hire engineers that possess attributes beyond the traditional education commonly offered. Engineers of today must understand the social, political, cultural and environmental impacts of technology and innovation.

Engineering graduates from traditional programs are lacking in skills required to be successful after graduation. This engineering dual degree program encompasses the liberal arts, experiential 
education, and cultural and international exposure producing engineers ready for the real-world work environment.

The Engineering Dual Degree Program (EDDP) results from the partnership between two wellestablished programs at Butler University and the Purdue School of Engineering and Technology at Indiana-University Purdue-University Indianapolis (IUPUI). The EDDP allows students to study at Butler University, a small private school, which is known for its quality science, humanities, social science, fine arts, and professional programs and also have access to ABET accredited engineering programs at IUPIU, a large state school.

Completion of this program results in two degrees from both institutions. This program is not a 3-2 program where students are expected to transfer after three years to an engineering school to complete their studies. The EDDP has a curriculum that integrates engineering, science, mathematics, computer science, social sciences, humanities, and fine arts courses and allows residence at Butler University for the duration of the program. Students in the EDDP choose from a variety of major combinations to satisfy their interests: one in engineering and one in the sciences/social sciences. Engineering discipline options are currently biomedical, computer, electrical and mechanical; with the addition of energy and motorsports coming in fall 2011. There are seven degree options from Butler for students to choose from: biology, chemistry, computer science, economics, mathematics, physics, and science, technology \& society.

Unlike a 3-2 program, students are enrolled and taking courses at both universities throughout the entire five years of the program. This is possible because the two institutions are just a few miles apart from one another and faculty travel to the primary campus to teach engineering courses in the first three years. Students then commute between the two campuses during the final two years of the program. In the end, each student receives two bachelor's degrees- one from Purdue University at Indianapolis and a second from Butler University.

A survey was administered to EDDP and IUPUI engineering graduates to determine if students from this dual degree program are more prepared for work in the real world. Quantitative results will be given to administrations at both universities at the conclusion of the analysis, in an effort to improve both programs and better the experience of students at both institutions.

\section{$\underline{\text { Research Problem }}$}

While engineering education is mostly based on technical knowledge learned in the classroom, there are other factors that need to be considered when assessing if a student has been given the tools to be competitive upon graduation. During this research, questions will be addressed to heighten awareness within various aspects of education. Data was gathered from alumni as far back as 2004, as this is the first year the EDDP graduated students. Results will show exactly what the job search is like when students are looking for their first full time job after graduation, if students utilize any support services when searching for jobs, and what skills are believed to be essential to employers.

The goal of this paper is to answer three research problems: 1) Identify if students are receiving everything they need during school in order to enter the real world after graduation; 2) 
Determine if students from the dual degree program are more successful during their first time job search than those in the traditional program; 3) Confirm that there is a need for engineers to have a well-rounded education. If gaps are identified in either group which deserve attention, proper measures can be taken. If areas are identified as being useful with one group and lacking in the other, this can also be addressed.

\section{Literature Review}

\section{Dual Degree}

Some research attention has been focused on traditional three-two programs or Bachelors/Masters programs; however little has been focused on dual degree programs in engineering and non-technical fields. These dual degree programs produce engineering graduates who are well rounded and can function in the society of today and the future. One aspiration for the future education of engineers published by the National Academy of Engineering [NAE] states, "We aspire to engineers in 2020 who will remain well grounded in the basics of mathematics and science, and who will expand their vision of design through a solid grounding in the humanities, social sciences, and economics."

Through the incorporation of traditional engineering coursework and a strong background in the liberal arts, students become attractive candidates to employers. Employers are recognizing the deficiencies in traditional curricula in providing graduates with social skills. ${ }^{2}$ Dual degree program goals are the integration of engineering, the humanities, and social sciences throughout the program to develop the students' technical skills and ethical, historical, political, and economic insights which are so essential to the conduct of national and global affairs. ${ }^{7}$

There is ongoing national debate over the need for well-rounded education for engineers and the lack of programs that provide such an education. ${ }^{5}$ Dual degree programs can be the solution to this shortage. In fact the NAE states, "We aspire to an engineering profession that will rapidly embrace the potentialities offered by creativity, invention, and cross-disciplinary fertilization to create and accommodate new fields of endeavor, including those that require openness to interdisciplinary efforts with non-engineering disciplines such as science, social science, and business."

Researchers support the NAE by claiming that dual degree programs graduate a modern engineer who can work effectively in multi-functional and cross-discipline teams. ${ }^{7}$ They continue by stating graduates are able to not only appreciate the human and social perspective but also feel comfortable adopting this perspective. These graduates have the social understanding, human interaction and communication skills that the traditional engineering student does not possess.

Dual degree programs seek to educate graduates equally prepared to deal with the technical and societal contexts of the challenges facing humankind in the twenty-first century. ${ }^{7}$ Researchers continue by stating that the goal of these programs is to graduate not only excellent technical engineers, but engineers who have a sound foundation in effective communication, and an understanding of the ethical and social context of engineering designs and decision. ${ }^{7}$ Additional researchers further support this by saying that dual degree programs offer a winning formula for 
increasing the production of well-rounded engineering graduates. ${ }^{4}$ For engineers, "problem solving is hard work, and good solutions depend on a broad knowledge base and insightful questions."6

\section{$\underline{\text { Liberal Arts }}$}

The Accreditation Board of Engineering and Technology's [ABET] 2000 Criteria have a very clear set of expectations for engineering degree programs related to the integration of technical and non-technical disciplines. For employers, a drawback of the engineering graduate is a lack of breadth in terms of their ability to communicate, both verbally and in writing. In addition, graduates are lacking in background knowledge relating to public policy and political sciences issues. Goldberg's research states that current engineering curricula are not designed to provide the kind of breadth that is necessary to apply engineering concepts of design and analysis in nontraditional settings, and that breadth is attained through the completion of multiple degree programs in diverse areas. ${ }^{5}$ A problem for companies when looking to promote engineers is that they "lack of breadth of vision and the ability to communicate effectively, or take the lead."2

The inclusion of courses in the liberal arts with engineering curricula produces graduates that encompass a mixture of traits that companies desire. Success occurs in programs designed to provide the capable and motivated student with an excellent grounding in the liberal arts that is thoroughly integrated with the mastery of the skills and concepts that are fundamental to modern engineering thought. ${ }^{5}$ Heckert \& Lavelle support this by stating that desired engineering graduates come from programs that provide students the opportunity to enhance and enrich the depth and texture of the technical and non-technical integration already found in their engineering degree. ${ }^{7}$ A liberal arts education teaches broad learning objectives and specific learning skills through a broad range of courses in the humanities, arts and social sciences. The inclusion of study in the social sciences and humanities in engineering curricula is important because "it is important to teach students how to ask tough questions about their challenges."10

\section{Internships \& Co-operative Education}

For an engineering student, experiential education not only enhances the knowledge gained in the classroom, but teaches skills inaccessible in program curricula. The NAE report on the Engineer of 2020 describes the growing separation between the needs of industry and the focus of academia, and cites the desire to close this growing gap. ${ }^{9}$ The report also points out the accelerating "disconnect between the system of engineering education and the practice of engineering." Akins notes that "cooperative education opens a myriad of possibilities” and that "there is no substitute for blending practical application with theory learned in the classroom."1 Needed breadth of engineering graduates mentioned earlier is "often attained through extensive on-the-job training." 5

As the engineering profession continues to grow and expand, "the engineer of 2020 will need to be able to work independently, and still effectively interface with the team."8 McGrath continues to discuss that the combination of education with training enables the engineering student to more quickly become productive in the design and problem solving experience. ${ }^{8}$ Participating in 
real-world work co-op situations provides tremendous focus for the engineering student, illustrating how subject matter quickly becomes relevant. ${ }^{10}$

When seeking placement after graduation, students in an engineering program that requires industry experience are more desirable to companies and typically are offered higher salaries. Wessels \& Pumphrey found that cooperative education decreased job search time and positively influenced the likelihood of promotion and advancement once employed. ${ }^{13}$ In addition, engineering students with cooperative education experience earned more than their engineering cohorts who did not participate in cooperative education. ${ }^{3}$

\section{Cultural Diversity}

Engineering is a worldwide industry and graduates must be prepared to work in a global environment. In the workplace, engineers will need to interact with individuals who use different methods for solving human problems, sometimes based on fundamentally different ways of thinking and acting. ${ }^{12}$ According to Siller, Johnson, \& Pruden, for engineers to be successful in an increasingly global profession, they must be prepared to work for multinational engineering firms and on teams of engineers that can be located anywhere on the globe. ${ }^{11}$

Programs that not only incorporate liberal arts, but require students to take classes on cultural awareness and participate in international exposure, thru study abroad and/or foreign language, produce engineers that are ready to work in the global engineering economy. One of the major strengths of the dual degree program is the students' ability to receive an excellent liberal arts education that not only includes foreign language but also includes culture, history, and other traditional liberal education topics. ${ }^{11}$ This research continues by claiming that the program is intended to explicitly prepare graduates to work in the international engineering environment by supplementing language skills with cultural, political, and economic knowledge of the global environment.

The engineering profession is continually evolving by adapting to its environment and the needs of the community. Engineers cannot comprehensively solve problems unless they understand, assess, evaluate, and quantify the impacts their products and creations will have on society. ${ }^{10}$ Engineering programs need to "prepare today's engineers for the careers of the future, with due recognition of the rapid pace of change in the world and its intrinsic lack of predictability." 9 The NAE report says that "engineering education must address the technology and societal challenges and opportunities for the future.” A dual degree engineering program that encompasses the liberal arts, experiential education, and cultural and international exposure produces engineers for the future, ready for the real-world work environment.

\section{Research Methodology}

In order to properly define alumni preparation for the real-world, qualitative and quantitative research was conducted. Students from the EDDP and IUPUI are currently surveyed upon graduation to gather some data about employment. It has not been studied if there is a disparity between these groups of students. This research was conducted to determine where the programs 
can enhance students’ academic experience and better their preparation for work in the realworld.

The researchers are employees from both of the engineering programs with an interest in improving both programs. The researchers seek to determine in what areas the quality of education can be improved. The information gathered ultimately will not only benefit the researchers as they continue working with the programs, but the school, faculty, staff and current and future students.

\section{Method of Data Collection}

Data was collected through a survey administered directly to all interested alumni of the EDDP and Purdue School of Engineering and Technology at Indianapolis since 2004, as this is the first year students graduated from the dual degree program. In addition to the EDDP, IUPUI has a dual degree engineering program with the University of Indianapolis (U Indy). The U Indy and IUPUI dual engineering program is very small and only combines a physics major with engineering. The survey was created using an online survey tool, allowing a greater number of alumni to participate. Administering the survey online also helped to ensure confidentiality and anonymity. The alumni were informed of the survey through multiple mass emails. A secure link was created for alumni to complete the survey.

A total of 100 alumni chose to participate in the survey. Of the 100 responses, 13 were discarded due to lack of provided information. The remaining 87 responses were distributed into three groups: EDDP alumni (24), University of Indianapolis/IUPUI dual degree alumni (4), and IUPUI Engineering alumni (59). The researchers determined it would be best to create a separate grouping for these students as they are not in a traditional engineering program nor in the EDDP. Appendix A contains a comprehensive listing of the month and year each survey participant graduated and Appendix B shows the distribution of responses by engineering discipline.

\section{$\underline{\text { Research Questions }}$}

Research questions were developed to gather a large amount of data that can be evaluated to answer the research problems. The questions were compiled using an if/then system in the survey tool. The employment questions (3-10) were given based upon the previous question's response. Each participant was asked questions 10-14. The questions are:

1. Month and year of graduation

2. Major(s)

3. When did you receive your first job offer (related to your major)? Month and year

4. Did you accept?

a. Yes

i. Company and location (city and state)

ii. Date you started

iii. Position title

iv. Salary 
v. Are you still employed there?

1. Yes

2. No

a. Reason for leaving

b. New company

c. New position title

d. New salary

vi. Are you still in the same position?

1. Yes

2. No

a. New position title

b. New salary

c. How long were you in your first position before receiving this promotion?

b. No

5. Second job offer received:

a. Month and year

b. n/a - skip to 9

6. Did you accept?

a. Yes

i. Company and location (city and state)

ii. Date you started

iii. Position title

iv. Salary

v. Are you still employed there?

1. Yes

2. No

a. Reason for leaving

b. New company

c. New position title

d. New salary

vi. Are you still in the same position?

1. Yes

2. No

a. New position title

b. New salary

c. How long were you in your first position before receiving this promotion?

b. No

7. Third job offer received: 
a. Month and year

b. n/a - skip to 9

8. Did you accept?

a. Yes

i. Company and location (city and state)

ii. Date you started

iii. Position title

iv. Salary

v. Are you still employed there?

1. Yes

2. No
a. Reason for leaving
b. New company
c. New position title
d. New salary

vi. Are you still in the same position?

1. Yes

2. No

b. No
a. New position title
b. New salary
c. How long were you in your first position before receiving this promotion?

9. How many additional full-time job offers did you receive?

10. Which of the following resources did you utilize during your degree program to prepare you for work after graduation?

i. Individual meeting with Career Services

ii. Career Services Workshop(s)

iii. Career Planning Course

iv. Internship or co-op

v. Career Fairs

11. How important were the following non-technical components of your degree program during your job search? (5 scale; not important to very important)
a. Writing Skills
b. Communication Skills
c. Liberal Arts/Humanities Courses
d. Social Science Courses
e. Language Courses
f. Cultural Exposure
g. Ability to work in a team 
12. Did you participate in...

a. Research

b. International Experience

i. Short term (summer, one month or less)

ii. Semester

iii. Year

c. Service Learning Project

d. Experiential Learning (internships)

i. Number completed

ii. List companies worked for:

13. What traits do you think employers were looking for in potential candidates during your job search? (mark all that apply)

a. Apply basic engineering principles

b. Solve engineering problems

c. Consider several points of view and arrive at a conclusion

d. Plan, organize, and complete a task

e. Design and conduct an experiment

f. Continuously learn new skills and knowledge

g. Communicate effectively orally

h. Communicate effectively in writing

i. Work successfully as a member of a team

j. Take initiative

$\mathrm{k}$. Integrate mathematics and science into your work

l. Knowledge from humanities and the social sciences

$\mathrm{m}$. Evaluate the quality and validity of data, information and evidence

n. Understanding and appreciation of ethics and professionalism

o. Awareness of value of considering diversity and differences in cultures

p. Awareness of the impact of your work in a global context

q. Awareness of the importance of safety issues in your work

14. Use this space to provide additional comments (i.e. program pros/cons, likes/dislikes, job research resources, etc.)

\section{Research Tool Testing}

Survey questions were tested first with a number of faculty and staff members who work with both of the studied programs. The researchers feel these faculty and staff members have an understanding of the information they are attempting to gather for this study. The questions were also provided to a different cross-section of faculty and staff for review. Faculty and staff input is necessary because they possess greater insight into survey distribution and analysis. 
To analyze this information, responses were compiled by question. The research team then computed the statistics which relate to these sets. Each question was reviewed and analyzed regardless of how well it related to the other answers.

\section{Data Analysis}

In order to address the three research problems stated above, the researchers analyzed the data between responses of Engineering Dual Degree Program students, traditional engineering students (non-dual degree/IUPUI) and University of Indianapolis students in two categories. The first category analyzed the responses regarding actual offers and the job search process addressing the following four areas: first full-time offer, number of full-time offers, first promotion, and salary. The second category looked at the services used while in school and traits desired by employers.

\section{$\underline{\text { First Full-time Offer }}$}

This section evaluates the number of graduates that received at least one full-time offer and when that offer was received in relation to the graduation month.

\begin{tabular}{|l|c|c|c|c|}
\cline { 2 - 3 } \multicolumn{1}{c|}{} & \multicolumn{2}{|c|}{ Full-Time Offer } & \% Grads with & Avg. months \\
\cline { 2 - 3 } \multicolumn{1}{c|}{} & Yes & No & no offer & to offer* \\
\hline EDDP & 21 & 3 & $8.70 \%$ & 2.24 \\
\hline IUPUI & 51 & 8 & $13.56 \%$ & -4.86 \\
\hline U Indy & 2 & 2 & $50.00 \%$ & -0.5 \\
\hline
\end{tabular}

*Average months to offer is based upon date of graduation, a positive number reflects an offer $x$ number of months prior to graduation where a negative is an offer $x$ number of months after graduation.

\section{Table 1: First Full-Time Offer}

From Table 1, it is shown that EDDP students receive their offers an average of over two months before graduation. Unlike the IUPUI (non-dual degree) students who average receiving an offer almost five months after graduation. Although the number of University of Indianapolis (U Indy) alumni responses was low, the two that did report receiving offers averaged getting them within a month after graduation. Responses also show that, EDDP students received their first full-time job offer no more than two months after graduation while one IUPUI student reported not receiving the first offer until 45 months after graduation. Also found in Table 1, is that less than $9 \%$ of responding EDDP alumni did not receive an offer in their field of study, as opposed to over $13 \%$ of IUPUI alumni. Just half of the U Indy alumni reported receiving full-time offers.

Only 11 of the IUPUI alumni reported receiving a full-time job offer at least one month prior to graduation, just $18.6 \%$ of the respondents. Twelve of the EDDP alumni reported receiving at least one full-time job offer at least one month prior to graduation, a strong $50 \%$. Of those reporting they received their first offer in the same month of graduation, 7 were IUPUI students and 3 were in the EDDP, $11 \%$ and 12.5\% respectively. Of all respondents, $85 \%$ received a full- 
time offer in their field of study. Over 91\% of the EDDP alumni reported offers, five percent more than the IUPUI alumni.

This data shows that EDDP students not only receive job offers earlier than the traditional IUPUI engineering students, but more were able to find jobs in their field of study. In addition, the EDDP alumni received job offers earlier than their peers at IUPUI.

\section{Number of Full-time Offers}

Next is the total number of full-time offers received by the graduating student.

\begin{tabular}{|l|c|c|c|c|}
\cline { 2 - 5 } \multicolumn{1}{c|}{} & $\begin{array}{c}\text { \# with } \\
\text { offer }\end{array}$ & $\begin{array}{c}\text { Avg. \# of } \\
\text { offers }\end{array}$ & $\begin{array}{c}\text { \# with } \\
>1 \text { offer }\end{array}$ & $\begin{array}{c}\text { \% with } \\
>1 \text { offer }\end{array}$ \\
\hline EDDP & 21 & 1.81 & 6 & $28.57 \%$ \\
\hline IUPUI & 51 & 1.63 & 18 & $35.29 \%$ \\
\hline U Indy & 2 & 1 & 0 & $0.00 \%$ \\
\hline
\end{tabular}

Table 2: Number of Full-Time Offers

Of the respondents, EDDP alumni averaged 1.81 offers as opposed to 1.63 of IUPUI alumni. These numbers are fairly close to one another and do not show a significant difference. Also in Table 2, the percentage of IUPUI students with more than one offer was greater than the EDDP students. In addition, of all responses, the highest number of offers reported was 10 and was given by an EDDP alum.

\section{$\underline{\text { First Promotion }}$}

The researchers believe that EDDP alumni are promoted faster in their first job than traditional students.

\begin{tabular}{|l|c|c|c|}
\cline { 2 - 4 } \multicolumn{1}{c|}{} & $\begin{array}{c}\text { \# with } \\
\text { promotion }\end{array}$ & $\begin{array}{c}\text { \% with } \\
\text { promotion }\end{array}$ & $\begin{array}{c}\text { Avg. \# years } \\
\text { to promotion }\end{array}$ \\
\hline EDDP & 10 & $47.60 \%$ & 1.56 \\
\hline IUPUI & 18 & $35.30 \%$ & 1.83 \\
\hline U Indy & 1 & $50 \%$ & 3 \\
\hline
\end{tabular}

Note: Data is calculated based on only those who reported receiving at least one full-time offer, those with no offer were omitted.

\section{Table 3: Promotion}

As seen in Table 3, EDDP alumni are promoted sooner than the IUPUI alumni, on average of about 3 months earlier. Also over 47\% of EDDP alumni reported a promotion where just 35\% of IUPUI alumni were promoted from their first job. 
$\underline{\text { Salary }}$

The data below represents the information provided on salaries offered.

\begin{tabular}{|c|c|c|c|}
\hline Salary Range & EDDP & IUPUI & U Indy \\
\hline Under $\$ 40,000$ & 1 & 2 & 1 \\
\hline$\$ 40,000-44,999$ & 0 & 3 & 1 \\
\hline$\$ 45,000-49,999$ & 2 & 7 & 0 \\
\hline$\$ 50,000-54,999$ & 8 & 6 & 0 \\
\hline$\$ 55,000-59,999$ & 6 & 10 & 0 \\
\hline$\$ 60,000-64,999$ & 0 & 12 & 0 \\
\hline$\$ 65,000-69,999$ & 2 & 3 & 0 \\
\hline$\$ 70,000-74,999$ & 0 & 5 & 0 \\
\hline$\$ 75,000-79,999$ & 0 & 1 & 0 \\
\hline$\$ 80,000$ and up & 1 & 0 & 0 \\
\hline
\end{tabular}

Note: Responses include highest offer reported.

Table 4: Salary Offers

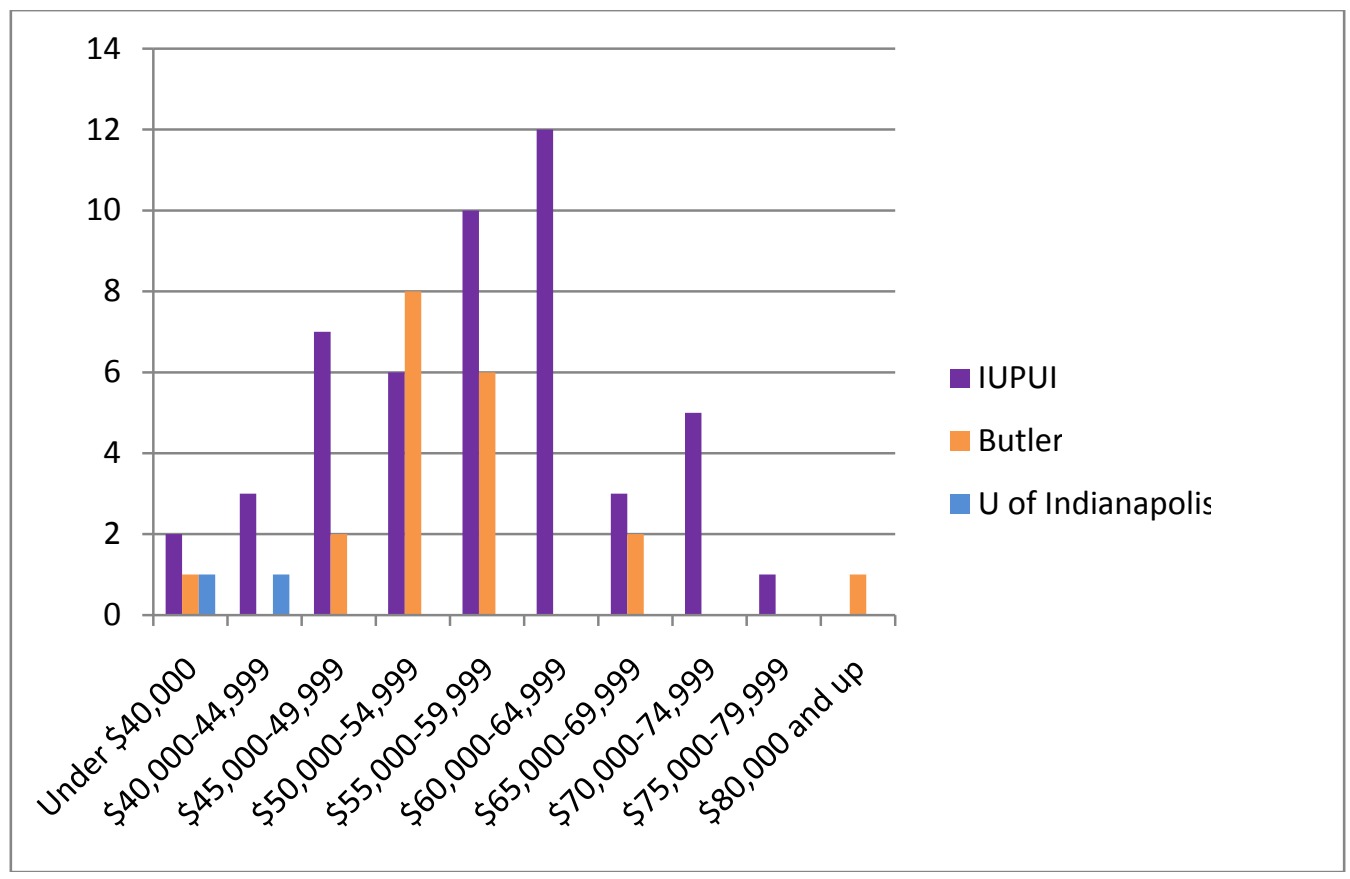

Figure 1: Salary Ranges

On average, IUPUI alumni reported offers of $\$ 55,000$ where EDDP alum reported $\$ 54,500$. If the two international offers are omitted, then the EDDP average is $\$ 55,500$ and IUPUI is $\$ 55,400$. The EDDP alumni only reported one offer below $\$ 45,000$ (4.55\%) where IUPUI alumni provided five (9.8\%). In addition, the highest response of an offer above $\$ 80,000$ came from an EDDP respondent. 
To address questions 10 thru 13 where alumni were asked about services used while in school and traits desired by employers, the researchers looked at trends in responses in both the entire population and the three groups.

Question 10 in the survey evaluated what services and opportunities were utilized by the responding alumni while they were in school.

\begin{tabular}{|c|c|c|c|c|c|}
\hline & \multicolumn{3}{|c|}{ Were you in a dual degree program? } & \multirow[b]{2}{*}{$\begin{array}{c}\text { Response } \\
\text { Percent }\end{array}$} & \multirow[b]{2}{*}{$\begin{array}{l}\text { Response } \\
\text { Count }\end{array}$} \\
\hline Answer Options & $\begin{array}{c}\text { Yes, } \\
\text { Butler/IUPUI }\end{array}$ & $\begin{array}{c}\text { Yes, University } \\
\text { of Indianapolis } \\
\text { /IUPUI }\end{array}$ & No & & \\
\hline $\begin{array}{l}\text { Individual Meetings } \\
\text { with Career Services }\end{array}$ & $\begin{array}{c}10 \\
(41.7 \%) \\
\end{array}$ & $\begin{array}{c}2 \\
(66.7 \%) \\
\end{array}$ & $\begin{array}{c}19 \\
(36.5 \%) \\
\end{array}$ & $39.2 \%$ & 31 \\
\hline $\begin{array}{l}\text { Career Services } \\
\text { Workshop(s) }\end{array}$ & $\begin{array}{c}10 \\
(41.7 \%)\end{array}$ & $\begin{array}{c}1 \\
(33.3 \%)\end{array}$ & $\begin{array}{c}14 \\
(26.9) \\
\end{array}$ & $31.6 \%$ & 25 \\
\hline $\begin{array}{l}\text { Career Planning } \\
\text { Course }\end{array}$ & $\begin{array}{c}6 \\
(25 \%) \\
\end{array}$ & 0 & $\begin{array}{c}2 \\
(3.8 \%) \\
\end{array}$ & $10.1 \%$ & 8 \\
\hline Internship or Co-op & $\begin{array}{c}18 \\
(75 \%) \\
\end{array}$ & $\begin{array}{c}1 \\
(33.3) \\
\end{array}$ & $\begin{array}{c}27 \\
(51.9) \\
\end{array}$ & $58.2 \%$ & 46 \\
\hline Career Fairs & $\begin{array}{c}19 \\
(79.2) \\
\end{array}$ & $\begin{array}{c}2 \\
(66.7) \\
\end{array}$ & $\begin{array}{c}38 \\
(73.1) \\
\end{array}$ & $74.7 \%$ & 59 \\
\hline None of the above & $\begin{array}{c}1 \\
(4.2 \%) \\
\end{array}$ & 0 & $\begin{array}{c}9 \\
(17.3) \\
\end{array}$ & $12.7 \%$ & 10 \\
\hline Answered Question & 24 & 3 & 52 & & \\
\hline
\end{tabular}

Table 5: Which of the following resources did you utilize during your degree program to prepare you for work after graduation?

The most frequently used resource was career fairs with almost $75 \%$ of all respondents reporting attending an event and more than half of the population participated in an internship or co-op. Seventy nine percent of EDDP alumni attended career fairs, above the average, compared to the below average $64 \%$ of IUPUI alumni. EDDP alumni were $30 \%$ more likely to have participated in an internship than the IUPUI alumni, at $75 \%$ versus $45 \%$ of the respondents. In addition, the single EDDP alumni who responded as not using any of the services/opportunities was also one of the two who reported never receiving a full-time offer in their field of study.

The information gathered in question 11 requested participants to rate how important the given non-technical components of their degree program were during the job search. 


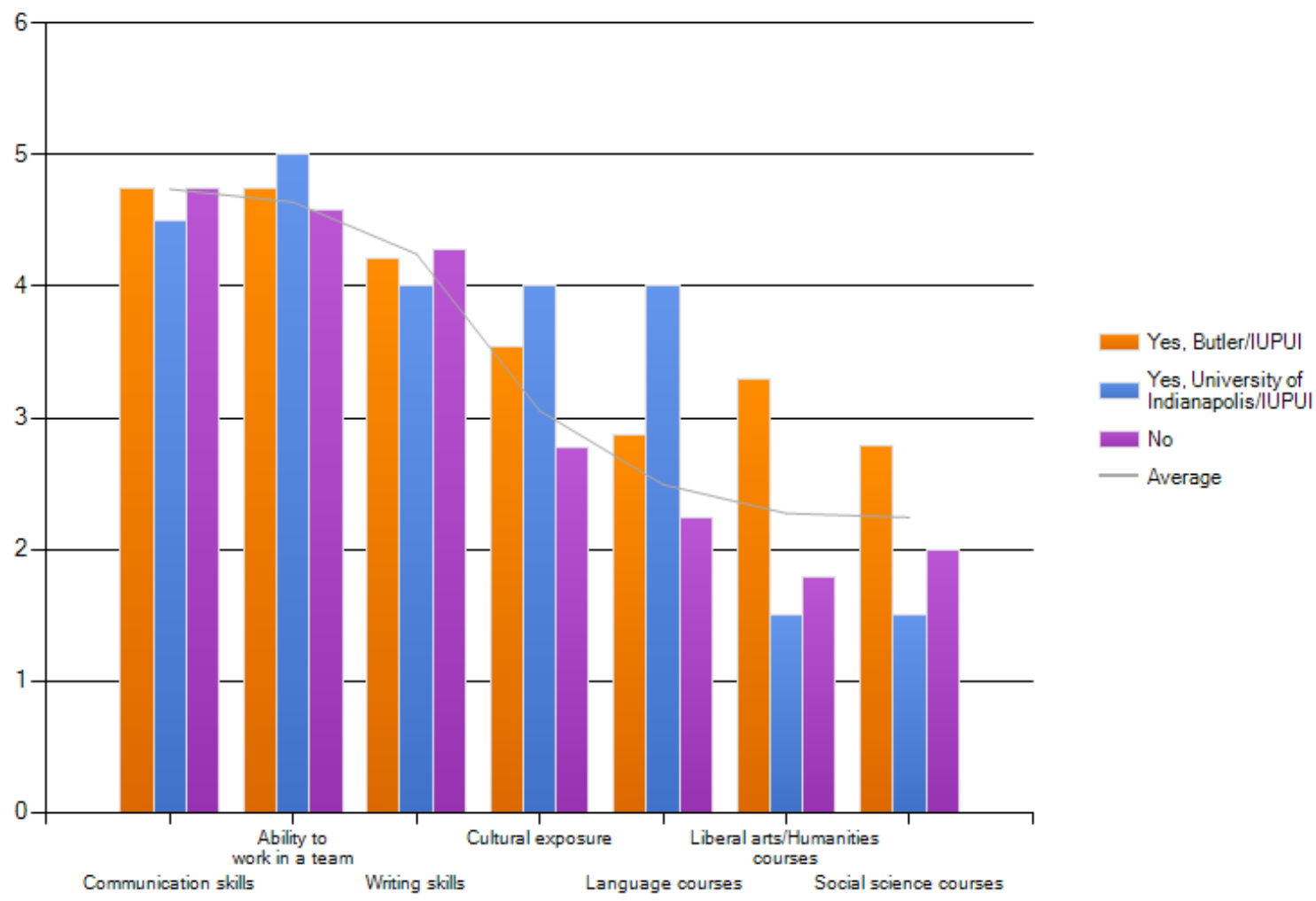

Figure 2: How important were the following non-technical components of your degree program during your job search?

The three most important non-technical skills, regardless of whether the student was dual degree or non-dual degree alumni were: communication skills, ability to work in a team, and writing skills. Both the EDDP and University of Indianapolis alumni ranked cultural exposure and language courses significantly higher than did the non-dual degree students. Not surprisingly, the EDDP students ranked liberal arts/humanities courses and social science courses higher than did the IUPUI students. However, it is surprising that the University of Indianapolis ranked those skills lower than did the non-dual degree students.

Question 12 addressed student participation in RISE (Research, International Study, Service Learning and Experiential Learning) programs. 


\section{Were you in a dual degree program?}

\begin{tabular}{|c|c|c|c|c|c|}
\hline Answer Options & $\begin{array}{c}\text { Yes, } \\
\text { Butler/IUPUI }\end{array}$ & $\begin{array}{c}\text { Yes, } \\
\text { University of } \\
\text { Indianapolis/ } \\
\text { IUPUI }\end{array}$ & No & $\begin{array}{c}\text { Response } \\
\text { Percent }\end{array}$ & $\begin{array}{c}\text { Response } \\
\text { Count }\end{array}$ \\
\hline Research & $\begin{array}{c}10 \\
(50 \%)\end{array}$ & $\begin{array}{c}2 \\
(66.7 \%)\end{array}$ & $\begin{array}{c}22 \\
(64.7 \%)\end{array}$ & $59.6 \%$ & 34 \\
\hline $\begin{array}{l}\text { International } \\
\text { Experience, short term } \\
\text { (summer, one month or } \\
\text { less) }\end{array}$ & $\begin{array}{c}8 \\
(40 \%)\end{array}$ & 0 & $1(2.9 \%)$ & $15.8 \%$ & 9 \\
\hline $\begin{array}{l}\text { International } \\
\text { Experience, semester }\end{array}$ & $\begin{array}{c}1 \\
(5 \%)\end{array}$ & 0 & $2(5.9 \%)$ & $5.3 \%$ & 3 \\
\hline $\begin{array}{l}\text { International } \\
\text { Experience, year }\end{array}$ & 0 & 0 & 0 & $0.0 \%$ & 0 \\
\hline $\begin{array}{l}\text { Service Learning } \\
\text { Project }\end{array}$ & $\begin{array}{c}3 \\
(15 \%)\end{array}$ & 0 & $\begin{array}{c}5 \\
(14.7 \%)\end{array}$ & $14.0 \%$ & 8 \\
\hline $\begin{array}{l}\text { Experiential Learning } \\
\text { (internships or co-op } \\
\text { sessions) }\end{array}$ & $\begin{array}{c}14 \\
(70 \%)\end{array}$ & $\begin{array}{c}2 \\
(66.7 \%)\end{array}$ & $\begin{array}{c}18 \\
(52.9 \%)\end{array}$ & $59.6 \%$ & 34 \\
\hline Answered question & 20 & 3 & 34 & & 57 \\
\hline
\end{tabular}

Table 6: Did you participate in any of the following (RISE)?

For traditional IUPUI students research was more common than experiential education. EDDP students, however, favored experiential learning more often than research. It is not surprising that EDDP students reported participating in experiential learning more than the others, since the program requires the completion of at least one internship. However, this requirement can be substituted with research if the student is planning on continuing into a graduate program, which is why all respondents did not complete an internship in industry. The University of Indianapolis students reported participating in research and in experiential learning equally.

Service learning was equally reported by both EDDP and IUPUI alumni. Short term (summer, one month or less) international experiences were much more common for the EDDP alumni than semester-long experiences. This is likely because of the rigors of the dual degree program during the academic year and the unavailability of needed courses during the summer break.

Finally, question 13 asked participants to select traits that they believe employers were looking for in candidates during their first job search. 


\section{What traits do you think employers were looking for in potential candidates during your job search? Mark all that apply.}

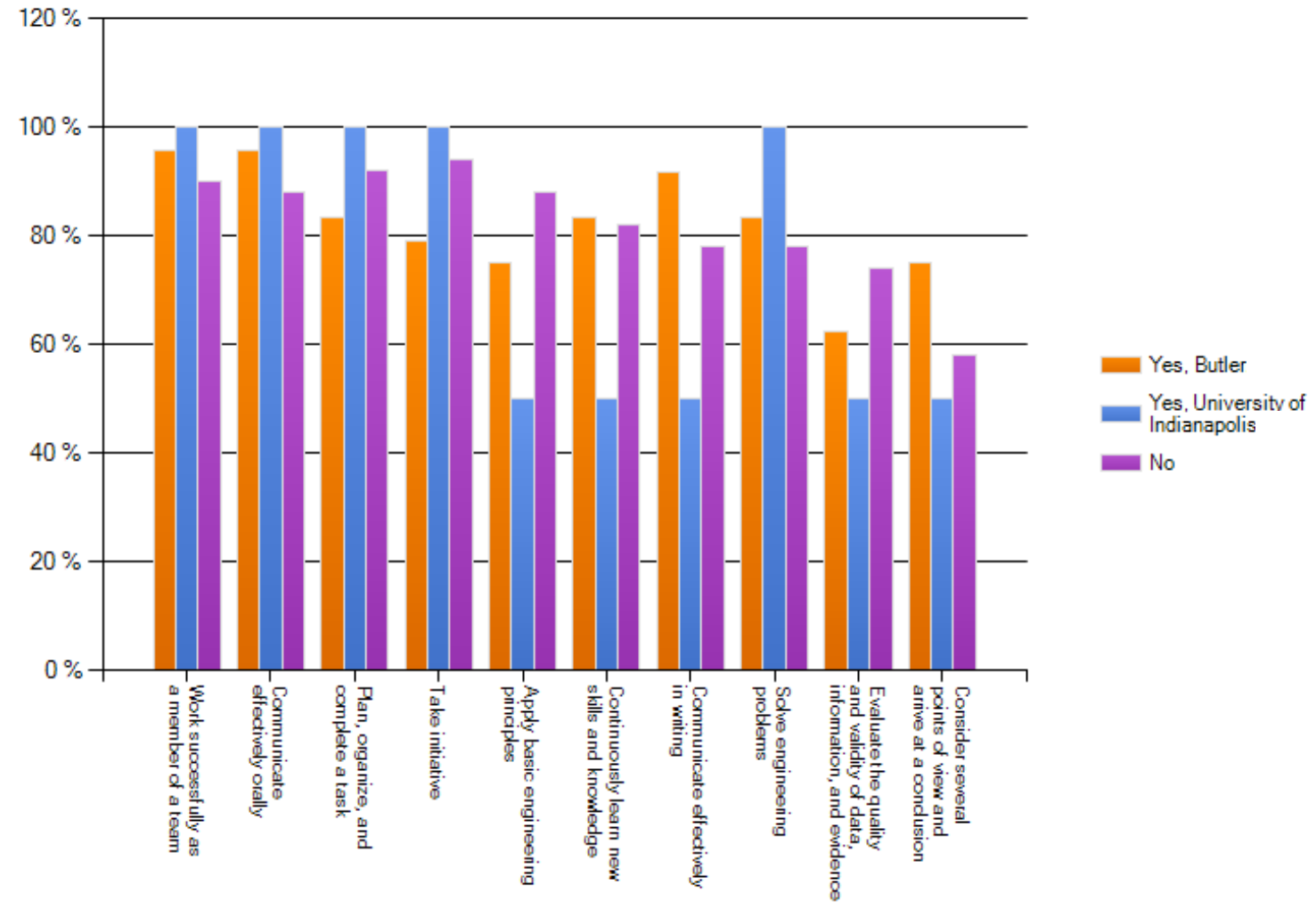

Figure 3: What traits do you think employers were looking for in potential candidates during your job search?(only a portion of options are shown)

Top traits for the EDDP respondents were: work successfully as a team (96\%), communicate effectively orally (96\%), and communicate effectively in writing (92\%). Top traits selected by the IUPUI respondents were: take initiative (80\%), plan, organize, and complete a task (78\%), and work successfully as a team (76\%). The trait selected least often was 'knowledge from humanities and the social sciences', selected by $12.5 \%$ of the EDDP alumni, $6.8 \%$ of IUPUI alumni, and by none of the University of Indianapolis alumni.

Only the data from the survey responses was used in this evaluation. Each year the EDDP collects employment information from every graduating student. This is possible because of the small number of graduates, approximately twelve each year. This information was not used unless it was provided in the administered survey. Also, the Purdue School of Engineering and Technology at Indianapolis gathers graduate information annually. Like the EDDP records, this data was not included in the analysis of this research. 


\section{Conclusions}

Overall, the responses were positive and provided a good basis for answering the three research problems stated earlier. The survey results were helpful in allowing the researchers to determine if their theories on the benefits of the Engineering Dual Degree Program were valid, as well as supportive of the research of other dual degree programs. The majority of the participant responses were supportive of the three research problems and confirmed the success of the EDDP alumni.

The first research problem asked if students received everything they needed during school in order to enter the real-world after graduation. Employers hire candidates that they know are ready to enter the workforce and contribute to their company. The alumni overall had a good placement rate. However EDDP students were more likely to be offered a full-time job after graduation. This confirms the theory that the dual degree alumni from the EDDP are better prepared to enter the real world.

To address the research problem that inquired if students from the dual degree program are more successful during their first time job search than those in the traditional program, the researchers looked at four areas: first full-time offer, number of full-time offers, promotion and salary. The data showed that the EDDP students were more likely to be offered a full-time job in their field of study after graduation. It is also revealed that the EDDP students received these offers earlier than the traditional engineering students. In addition, the dual degree students average more offers during their first full-time job search. Once employed, the EDDP respondents were promoted at a faster rate than their peers in the traditional engineering program.

The final research problem asked if there is a need for engineers to have a well-rounded education. Since it has been shown that the EDDP students are more successful during their first full time job search, one would think that the need does exist. In addition, all the responses rated it is, at least, somewhat important to have five of the seven non-technical components (communication and writing skills, the ability to work in a team, cultural exposure, and language courses) while searching for jobs. The EDDP students rated all seven as at minimum somewhat important. Including these skills, traits and abilities in an academic program from the beginning allows students to be better prepared to enter the real world after graduation. A dual degree program is one solution to the ongoing national debate over the need for well-rounded education for engineers as described by Goldberg. ${ }^{5}$ In addition, both the EDDP and IUPUI students responded by more than $60 \%$ that employers were looking for all the traits in potential candidates.

While overall the responses from the survey supported the researchers' theory about the Engineering Dual Degree Program, some results were unexpected. It was expected that the salaries offered to EDDP students would be higher, by at least one range, which was not the case. Also, more of the IUPUI alumni reported receiving multiple offers than the dual degree students. One reason for these results to be higher than expected is that IUPIU students tend to be older as a population and a number of them have related work experience already. 
The researchers plan to conduct additional research and analyze results further to determine what other differences can be found. Included will be the data recorded annually by both programs. Also, the survey data can be further analyzed to see if there are variations between engineering disciplines when answering the three research problems and may provide useful results that vary by major. In addition, not all students enter the workforce immediately, especially in their field of study. The researchers have an interest to see what the respondents did after graduation who answered that they did not receive a full-time offer. There has also been a large shift in the U.S. economy since 2004 and the data from each year will likely vary.

\section{Bibliography}

1 Akins, T. (2004) A Brief Summary of Cooperative Education: History, Philosophy, and Current Status, Georgia Institute of Technology, excerpted from Educating the Engineer of 2020, The National Academies Press, 2005.

2 Beder, S. (1999). Beyond Technicalities: Expanding Engineering Thinking. Journal of Professional Issues in Engineering Education, January 1999, 12-18.

3 Blair, B., Millea, M., \& Hammer, J. (2004). The Impact of Cooperative Education on Academic Performance and Compensation of Engineering Majors. Journal of Engineering Education, October 2004, 333-338.

4 Collision, M. K. (1999). The Power of Partnerships. Black Issues in Higher Education, 16 (10), 26.

5 Goldberg, J. (2003). Bachelor of Arts in Engineering Program at the University of Arizona. Proceedings of the 2003 American Society for Engineering Education Annual Conference. American Society for Engineering Education. CD-ROM, Session 2561.

6 Heinig, E. M. (2005, July/August). Engineering Education: Reform Now, The Future is at Stake. IEEE Power \& Energy, 88-89.

7 Herkert, J. \& Lavelle, J. (2005). “Write things worth reading, or do things worth the writing:” A dual-degree program in engineering and the liberal arts. Proceedings of the 2005 American Society for Engineering Education Annual Conference. American Society for Engineering Education. CD-ROM, Session 2161.

8 McGrath, M. (2006). Bridging the Gap to the Engineer of 2020. Proceedings of the 2006 American Society for Engineering Education Annual Conference. American Society for Engineering Education. CD-ROM, Session 2564.

9 National Academy of Engineering. (2005). The Engineer of 2020: Visions of Engineering in the New Century. Washington, D.C.: The National Academies Press.

10 Roman, H. T. (2004, May/June). Reengineering Education: A change is needed in U.S. Engineering Education. IEEE Power \& Energy, 84-86.

11 Siller, T., Johnson, G., \& Pruden, A. (2006). Offering an International Degree Program as a Dual Degree with Liberal Arts. Proceedings of the 2006 American Society for Engineering Education Annual Conference. American Society for Engineering Education. CD-ROM, Session 1054.

12 Steneck, N. H., Olds, B. M., \& Neeley, K. A. (2002). Recommendations for Liberal Education in Engineering: A White Paper from the Liberal Education Division of the American Society for Engineering Education. Proceedings of the 2002 American Society for Engineering Education Annual Conference. American Society for Engineering Education. CD-ROM, Session 1963.

13 Wessels, W. \& Pumphrey, G. (1996). The Effects of Cooperative Education on Job Search Time, Quality of Job Placement and Advancement. Journal of Cooperative Education, 31 (1), 42-52. 


\section{$\underline{\text { Appendix A }}$}

\begin{tabular}{|l|c|c|c|c|c|}
\hline & \multicolumn{2}{|c|}{ Were you in a dual degree program? } & \multicolumn{1}{l|}{} \\
\hline Answer Options & $\begin{array}{c}\text { Yes, } \\
\text { Butler/IUPUI }\end{array}$ & $\begin{array}{c}\text { Yes, University of } \\
\text { Indianapolis/IUPUI }\end{array}$ & No & $\begin{array}{c}\text { Response } \\
\text { Percent }\end{array}$ & $\begin{array}{c}\text { Response } \\
\text { Count }\end{array}$ \\
\hline May 2003 & 0 & 1 & 2 & $3.4 \%$ & 3 \\
\hline August 2003 & 0 & 0 & 0 & $0.0 \%$ & 0 \\
\hline December 2003 & 0 & 0 & 2 & $2.3 \%$ & 2 \\
\hline May 2004 & 2 & 0 & 3 & $5.7 \%$ & 5 \\
\hline August 2004 & 1 & 0 & 0 & $1.1 \%$ & 1 \\
\hline December 2004 & 0 & 0 & 2 & $2.3 \%$ & 2 \\
\hline May 2005 & 4 & 0 & 3 & $8.0 \%$ & 7 \\
\hline August 2005 & 1 & 0 & 0 & $1.1 \%$ & 1 \\
\hline December 2005 & 0 & 0 & 2 & $2.3 \%$ & 2 \\
\hline May 2006 & 2 & 0 & 2 & $4.6 \%$ & 4 \\
\hline August 2006 & 0 & 0 & 0 & $0.0 \%$ & 0 \\
\hline December 2006 & 0 & 0 & 1 & $1.1 \%$ & 1 \\
\hline May 2007 & 1 & 0 & 5 & $6.9 \%$ & 6 \\
\hline August 2007 & 0 & 0 & 0 & $0.0 \%$ & 0 \\
\hline December 2007 & 0 & 0 & 1 & $1.1 \%$ & 1 \\
\hline May 2008 & 2 & 0 & 6 & $9.2 \%$ & 8 \\
\hline August 2008 & 0 & 0 & 1 & $1.1 \%$ & 1 \\
\hline December 2008 & 0 & 0 & 3 & $3.4 \%$ & 3 \\
\hline May 2009 & $\mathbf{7}$ & 0 & 7 & $16.1 \%$ & 14 \\
\hline August 2009 & 0 & 1 & 2 & $3.4 \%$ & 3 \\
\hline December 2009 & 2 & 0 & 5 & $8.0 \%$ & 7 \\
\hline May 2010 & 2 & $\mathbf{2}$ & $\mathbf{1 1}$ & $\mathbf{1 7 . 2 \%}$ & $\mathbf{1 5}$ \\
\hline August 2010 & 0 & 0 & 1 & $1.1 \%$ & 1 \\
\hline December 2010 & 0 & 0 & 0 & $0.0 \%$ & 0 \\
\hline
\end{tabular}

*Bolded responses indicate greatest number in each group. 


\section{Appendix B}

\begin{tabular}{|l|c|c|c|c|c|}
\hline & \multicolumn{2}{|c|}{ Were you in a dual degree program? } & \\
\hline Answer Options & $\begin{array}{c}\text { Yes, } \\
\text { Butler/IUPUI }\end{array}$ & $\begin{array}{c}\text { Yes, University of } \\
\text { Indianapolis/IUPUI }\end{array}$ & No & $\begin{array}{c}\text { Response } \\
\text { Percent }\end{array}$ & $\begin{array}{c}\text { Response } \\
\text { Count }\end{array}$ \\
\hline Mechanical Engineering & 9 & 1 & 30 & $46.0 \%$ & 40 \\
\hline Biomedical Engineering & 0 & 1 & 8 & $10.3 \%$ & 9 \\
\hline Computer Engineering & 3 & 1 & 3 & $8.0 \%$ & 7 \\
\hline Electrical Engineering & 12 & 1 & 17 & $34.5 \%$ & 30 \\
\hline $\begin{array}{l}\text { Interdisciplinary } \\
\text { Engineering }\end{array}$ & 0 & 0 & 1 & $1.1 \%$ & 1 \\
\hline
\end{tabular}

*The Biomedical Engineering program did not graduate students from IUPUI until 2008 and until 2010 from Butler. 